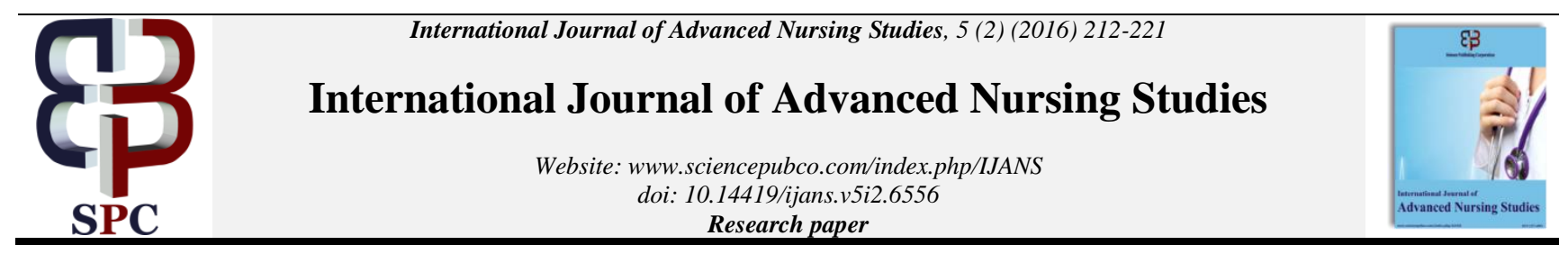

\title{
An educational programme to facilitate critical thinking within the nursing perspective
}

\author{
Louise Pretoruis $^{1 *}$, Agenus Van Dyk ${ }^{2}$, Luis F Small ${ }^{1}$, Hans Justus Amukugo ${ }^{1}$ \\ ${ }^{1}$ Lecturers, School of Nursing and, Faculty of health Sciences University of Namibia \\ ${ }^{2}$ Full Professor and Dean School of Nursing Lecturer, International University of Management \\ *Corresponding author E-mail: lpretorius@unam.nam
}

\begin{abstract}
This article is focuses on an educational programme to facilitate critical thinking within the nursing perspective. For the purpose of developing an educational programme; the study was conducted in four phases, beginning with a needs assessment in Phase 1 through which the researcher determined the need of student nurses in terms of critical thinking. The deductive data analysis of phase 1 served as conceptual framework for the development of education programme in phase 2 .

Phase 2 consisted of the development of educational framework to facilitate critical thinking in student nurses. Specific educational approaches and a philosophical framework were employed during the development of the programme. An expert opinion on the programme was obtained before the implementation could be concluded in phase 3 . Phase 3 and 3 of the study were conducted simultaneously. Phase 3 covered the implementation of the educational programme and Phase 4 the evaluation.

The process itself includes, the purpose of the development of the programme, conducting a situational analysis; utilization of philosophical approaches, developing the educational programme; content of the programme; educational and curriculum approaches integrated into the development of an educational programme and strategies to overcome obstacles during the implementation of an educational programme.
\end{abstract}

Keywords: Process; Educational Programme; Facilitate; Critical Thinking and Nursing Perspective.

\section{Introduction}

Nursing all over the world is faced with the challenge of teaching students from varying backgrounds and diverse cultures (Richardson, 1998) and Namibia is no exception to this phenomenon. Preparing future professionals in the health sciences require making judgments in highly complex environments (Facione et. al., 1997). The preparation of these professionals includes the development of critical thinking. Critical thinking has become one of the benchmarks that are used to measure successful learning outcomes of students today. In the rapidly changing arena of health care, professional nurses must have critical thinking skills and use them to deliver optimal care. One way of achieving this is by offering an educational programme (Jenkins \& Turick-Gibson, 1999; Gellin \& Beard, 2007).

It is evident in literature that educators should move away from unilateral teaching such as lecturing which promotes dependency and passivity. Educators must be willing to examine and implement strategies that will provide participatory, meaningful and stimulating learning for the students, targeting their educational needs and priorities with self-esteem and authority. Educators are therefore challenged to identify measures and justify thoughtful, fair-minded engagement in problem solving, decision making and professional judgments which are all indicative of critical thinking. It is also emphasized that through practice and with guidance from a good facilitator, we can develop our thinking skills as far as our natural abilities allow (Pond et. al., 1991; Facione et al., 1997; Fichardt \& Viljoen, 2000; Facione, Facione \& Giancarlo, 2000; Banning, 2005).
This article addressed the development of a programme to facilitate critical thinking in student nurses, to meet the above challenge. Initially, an overview of and rationale for the educational programme were provided and the approaches utilized to guide the development of the educational programme were discussed. It is also important to mention that the main focus of the programme was to help the student to acquire skills in a "learn by doing" approach since the programme emphasized active participation by the student (ADEA, 2006, p.931). The researcher strove to contribute towards the development of the individual's capacity for personal and social growth. "It was all about people" (Anastasi, 2004). The researcher's vision in designing an educational programme to facilitate the development of critical thinking skills in the student nurse was to develop the skills of nurses in Namibia so that they would be able to face the challenges of the nursing profession in that country. It was envisaged that the students should finish the educational programme with a knowledge base and skills in critical thinking that they had not expected to acquire at the beginning of the programme.

It is essential, however, to realize that it is necessary to adapt whatever is taught to nursing students to address the needs of the individual student and to adapt the teaching strategies accordingly (Richardson, 1998, p.17; CTL, 2005, p.1). Furthermore it should be kept in mind that the student profile has changed tremendously over the past years, which requires the educator to be flexible in considering adult education principles.

Although some authors like Van Gelder (n.d,) see the development of critical thinking as a lifelong journey that cannot be taught overnight, it is also essential to start somewhere in the development of critical thinking. Educators should begin infusing the 
concept, since "it is never too early or too late to start working on it" (Van Gelder, n.d, p. 3; Sternberg \& Spear-Swerling, 1996; Abegglen, 1997).

The researcher is aware of the fact that students cannot be skilled in critical thinking after a short programme on critical thinking, but is confident that the educational programme will sensitize advanced thinkers in nursing to start developing their critical thinking skills so that the nurses of Namibia become "smart" in the execution of their nursing tasks. It is also the responsibility of an educator to provide as many opportunities as possible to the students to develop within a certain context .Learning is not the result of development, it is development. It requires selforganization from the prospective learner (Fosnot, 1996, p 29; Mentkowski \& Associates, 2000, p. 58).

It is true that incorporating critical thinking into teaching pose challenges to the teacher, but those who do this in the right spirit and with dedication will be rewarded by observing clients receiving quality care

The American Association of Colleges of Nursing and the National League for Nursing support the inclusion of critical thinking as an outcome criterion and central competency for nursing education programmes (Applegate, 1998,; Redding, 2001,; Stone, Davidson, Evans \& Hansen, 2001; Oberleitner, n.d.,). However, this is a fairly new concept to nursing education. As late as 1991, nursing education played a "nominal role in the development of critical thinking" (Oberleitner, n.d,). Redding (2001), is confident that higher education (including nursing education) is designed to foster the development of intellectual competencies and skills including critical thinking skills. At the same time, it was also indicated that critical thinking can be taught in several ways, with specific reference to a separate course/ programme (Wright, 2002).

To emphasize the importance of the concept of critical thinking, it should be remembered that higher education is constantly in the limelight and comes in for criticism on whether the programmes they offer prepare their graduates adequately to perform in their field of interest. It is considered that taking difficult classes develops the brain more than taking easy classes. This implies that sessions, in programmes, that challenge critical thinking will produce more results than straightforward sessions (Mentkowski \& Associates, 2000; Jensen, 2006). Therefore, in the light of the above the researcher considered it applicable and appropriate to develop an educational programme for final-year nursing students to facilitate the development of their critical thinking skills in nursing practice before they enter nursing as professionals.

The educational programme that was developed for the study was in line with the educational expectation that a programme should have a specific focus, based on a needs assessment. This is in fact considered to be crucial in the development of a programme (Fichardt \& Viljoen, 2000; Thorpe \& Loo, 2003).

The focus of this educational programme was to facilitate the development of critical thinking in student nurses to increase their ability to solve problems and improve the quality of nursing care within the Namibian context. An integral part of this programme was to teach participants in the programme (the student nurses) how to use critical thinking to synthesize knowledge and abilities in providing holistic care for clients/patients across their life span. Given that we can never anticipate every possible problem, educating people to think remains our best chance of solving the problems that come our way (Facione, Facione \& Giancarlo, 1997(b) Boland, 1998; Finke \& Boland, 1998; Fichardt \& Viljoen, 2000; Thorpe \& Loo, 2003).

\section{2. purpose of the study}

The general purpose of nursing research is to answer questions or solve problems relevant to the nursing profession (Polit \& Beck, 2006, p. 19). The specific purpose of this study was to develop, implement and evaluate an educational programme that will promote critical thinking among student nurses in order to empower them to practise critical thinking as professional nurses after completing their studies.

\section{Objectives of the study}

The objectives of the study were to:

- Conduct a needs assessment on the needs of the student nurse in Namibia regarding critical thinking in nursing practice

- Develop an educational programme to facilitate critical thinking among student nurses in nursing practice

- Implement and evaluate an educational programme to facilitate critical thinking among student nurses in nursing practice

\section{Methodology}

In the light of the above arguments and with literature support relating to the essence and applicability of educational programmes in the development of critical thinking in nursing education, the researcher developed an educational programme (phase 2) to facilitate critical thinking in the student nurse. The process includes, the purpose of the development of the programme, conducting a situational analysis; utilization of philosophical approaches, developing the educational programme; content of the programme; educational and curriculum approaches integrated into the development of an educational programme and strategies to overcome obstacles during the implementation of an educational programme

\subsection{Purpose}

The purpose of phase two (2) of the study was to develop an educational programme within a conceptual framework. The nature, content and extent of the educational programme focused on the facilitation of the development and application of essential critical thinking skills which every nurse practitioner should master in nursing practice. This would enable the student nurse to render quality care to their clients /patients.

\subsection{Conducting a situational analysis}

The development of the educational programme was strengthened by the need that was identified in Namibia, namely that nursing students do not apply critical thinking skills in their management of patients and rendering of client/patient care. The fact that Namibian nurses fail to apply critical thinking skills in the execution of their daily nursing tasks has been identified as a challenge to nursing education in Namibia.

\subsection{Philosophical approaches}

The researcher incorporated the philosophy of humanistic existentialism as well as the principles of constructivism that support existentialism into the programme.

Humanistic existentialism, although the philosophical approach to the research has already been described in chapter 1 , the researcher anticipated the integration of philosophical assumptions into the development of the educational programme.

The philosophical basis of an educational programme refers to the underlying values and beliefs that influence and direct the programme structure and its substance. It is important that the development of the programme be in line with the philosophy and mission statement of the institution. These describe the unique purpose and reason for the existence of an institution (Csokasy, 1998).

The educational programme was developed within the philosophical approach of humanistic existentialism, which is in line with the mission statement of the Faculty of Medical and Health Sciences 
at the University of Namibia where nursing students are trained Humanistic existentialism focuses on individualism and selffulfillment, choices that need to be made, freedom of choice, meaning of choice and the responsibility one has for choice that indicates that a person is uniquely responsible for his/her own fate It is believed that individuals are faced with freedom of choice to participate in the programme and that the development of critical thinking in the student and professional nurse remains a personal choice (Praeger, 1995; Dillard \& Laidig, 1998) .

For the development of this educational programme the researcher focused on the student nurse as an individual on the verge of becoming a professional nurse who is responsible for the rendering of comprehensive health care. Rendering comprehensive health care involves the ability to identify and address the health needs of the nation of Namibia to render a service, especially in the domains of preventive, promotive, curative and rehabilitative health care.

In order to be able to render comprehensive health care, the student nurse has to develop as a critical thinker to empower him/herself to exercise professional judgment which will ensure that the Namibian public will receive high quality safe, professionally and ethically based health care (Faculty of Medical and Health Sciences- objectives, UNAM). The above-mentioned is in line with the view of Shaw (2006) on the existentialistic approach. Shaw says that in the class of the existentialist, subject matter takes second place to helping the students understand and appreciate themselves as unique individuals who accept complete responsibility for their thoughts, feelings and actions.

Humanistic existentialism as a philosophical approach to the study implied furthermore that student nurses should become aware of their ability to realize their potential, should have freedom of responsibility and in relation to others strive to find themselves in this process of developing critical thinking. Moreover, as human beings we should realize that we live in a world of complexities and possibilities and we all have the responsibility for making the most of this existence. Existentialism is particularly applicable to nursing because of its emphasis on self-determination, freedom of choice and self-responsibility (Praeger, 1995; Dillard \& Laidig, 1998). A structure supportive of the philosophy of humanistic existentialism is one of the principles of constructivism which also supports the learner as a unique individual with unique backgrounds and needs.

The constructivist paradigm, also referred to as the naturalistic paradigm, began as a counter movement to positivism and represents an alternative system for inquiry (Polit\& Beck, 2006).It may also be considered a philosophical framework of learning. For the constructivist /naturalistic inquirer, reality is not fixed and many constructions are possible. In research, constructivism relates findings to the interaction between the inquirer and participants ( Polit \& Beck 2006; Wikipedia ,n.d (a)).

For the educational principles and approach the constructivism focuses on the learner with multiple interpretations in mind, and where interaction among the learner and other stakeholders in the education process are important. The emphasis in the constructivist approach is on facilitator-supported learning, initiated and directed by the learner (Wikipedia ,n.d (a)).

Constructivism emphasizes the involvement of the learner/student in his own learning to construct and create new ideas from previous experience. It is thus important that the learner is given the opportunity to voice his experience and to allow as many construction of a situation as possible. The principles of constructivism as applied to this educational programme were as follows:

- Real-world environments were incorporated into the programme, which assisted the participants to focus on everyday world problems in terms of case scenarios. However, conditions during the implementation of the programme allowed for different interpretations of a given situation which facilitated active participation by the participants of the educational programme

- The facilitator of the educational programme (researcher) served as the coach to facilitate thoughts and strategies to solve these problems but participants were allowed freedom of thought and construction.

- The presentation of the educational programme focused on knowledge construction and not reproduction (see chapter 7).

- Reflective practice was fostered because constructivism allows and emphasizes understanding of a situation and not merely a reproduction as already mentioned.

- Multiple modes of presentation were encouraged which provided for the uniqueness of the learner/participant while allowing the learner to develop and individual potential.

- Self-awareness in the construction of knowledge was emphasized (Murphy, 1997; Savard, 2004; Polit \& Beck, 2006; Wikipedia, n.d (a)).

Except for the philosophical approaches, different educational approaches were also integrated into the development of the programme.

\subsection{Objectives of an educational programme}

The objectives for this educational programme were compiled to enhance the development of critical thinking skills among student nurses by focusing on the less obvious and by helping the nurse to develop a "why" attitude towards the obvious. To allow the students to learn to be self-aware and reflective, self-assessed and self-regarding, the educational programme needed to provide opportunities for reflective self-awareness, using a subtle approach and questioning attitude towards decisions made in the care of the patient (Robinson, 1998, p.4; Mentkowski \& Associates, 2000).

The following objectives were therefore developed for the educational programme:

The researcher

- Formulated objectives for the educational programme to facilitate the development of critical thinking in student nurses. These included sensitization of the group towards the term "critical thinking" and an introduction to critical thinking concepts.

- Outlined the content that had to be covered in the programme which was within the conceptual framework as discussed in chapter 5 .

- Explored, described and designed the strategies that will be followed during the implementation of the programme.

- Integrated the critical thinking concepts into nursing practice by constructing case scenarios.

- Drafted specific questions to strengthen the application of critical thinking concepts in the management of the case scenario.

- $\quad$ Peer-reviewed the proposed programme.

- Made the draft programme available to experts for validation

\subsection{Content of the programme}

The researcher employed specific teaching strategies during the educational programme to facilitate critical thinking. The strategies that were used are case scenarios and debating.

Case scenario:

With any educational programme and/or curriculum it is important to identify teaching strategies suitable to address or offer the content of the particular curriculum. This educational programme was no exception. After the design and the validation of the educational programme content, strategies for teaching were decided upon. Years back Sternberg (1985) believed that critical thinking should be taught by using instructional material that reflects the realities of thinking in real life, which is strongly supported by the constructivists. Students have to be confronted with real-life problems, in the form of case scenarios, to understand how critical thinking can be used in everyday situations. The presentation of real- life problems in these case scenarios happens to be not only useful for 
thinking, but also successful in the development of critical thinking (Cooke \& Moyle, 2002).

A case scenario is defined as an in-depth analysis of a real-life situation as a way to illustrate class content and theory to real or simulated life or both. It requires the student to be actively involved in the educational setting, constructing ideas and debating decisions around a specific problem in the form of a case scenario .This strategy is extremely useful in nursing education as a means of exposing students to a case that they may come across in order to encourage debating in the class to facilitate critical thinking on the solution to the problem (Rowles \& Brigham, 1998,; Cooke \& Moyle, 2002; Baumberger-Henry, 2005).

Debating of a case in a case scenario is "a realistic way to present didactic information in a more meaningful text" (Pond, Bradshaw \& Turner, 1991, p.18) and it may be a useful tool to teach students decision making and planning of care. It gives the individual the opportunity to use his/her knowledge base, deep-rooted ideas and assumptions to solve the problem (Thurmond, 2001; Souers, 2002).In constructivism the utilization of case scenarios is also seen as a means of challenging students. Constructivism examines how learning takes place, involving negotiation, with respect for and meaningful interpretation of ideas, making sense of an experience which is an excellent strategy to employ and fostering critical thinking because it calls for student interactions. Student interactions present students with the opportunity to practice and master their skills (Smith, 2002; Siegel, 2005; Baumberger-Henry, 2005) Therefore the researcher (and facilitator of the programme) decided to focus on the utilization of case scenarios in the presentation of this educational programme, designed to facilitate critical thinking in student nurses.

However, for this teaching strategy to be successful, cases should be well designed and realistic. These criteria applied to the case scenarios that were developed for this educational programme Furthermore the class environment should be non-threatening and peaceful. This is the responsibility of the facilitator, as described under the principles of adult education (Rowles \& Brigham, 1998; Baumberger-Henry, 2005).

The advantage of case scenarios is that they stimulate critical thinking, retention and recall on condition that they reflect the realities of everyday problem solving. Unless these criteria are met, it is doubtful that students will be able to apply what they have learned from these programmes in their everyday lives (Sternberg, 1985). For this educational programme different case scenarios were presented after the concepts had been lectured, to enable students to apply critical thinking skills to a general and nursing situation. By brainstorming for ideas during group work, students were given the opportunity to examine their own viewpoints and rethink old ideas to fit the needs of the client/patient. By doing this the facilitator enhanced active participation and self-directed learning (Pond et.al., 1991; Rowles \& Brigham, 1998; Cooke \& Moyle, 2002).

Debating:

In addition to case scenarios, debating can also be employed as a teaching strategy for the facilitation of critical thinking. The researcher attempted to enhance debating of relevant issues in groups so as to involve students in decision making. Debates are described as a valuable teaching method to enhance critical thinking in nursing. They also encourage students to exchange ideas on their decisions and outcomes. Debates can also be initiated by confronting students with real-life situations and thereby giving them the opportunity to apply their knowledge to solve problems and live the experience of their client/patient. It was also indicated that regular reflection on the debates would facilitate student learning. Debating can be a very successful exercise when it is done in small groups. Small group discussions promote communication in students who are quiet and nonverbal by nature. These students feel at ease when they can air their opinions in a small group (Abegglen, 1997; Jenkins \& Turick-Gibson, 1999,; Varner \& Peck, 2003; Candela, Michael \& Mitchell, 2003).

Throughout the discussion the researcher has indicated, integrated and discussed several strategies that can enhance active participa- tion and by doing that ultimately foster critical thinking. However, to summarize, the following strategies as indicated in table 1 , were employed to facilitate interaction during the implementation of an educational programme for the facilitation of critical thinking. This will also help participants in their everyday contact and communication with patients/clients:

Table 1: Strategies to Enhance Interaction

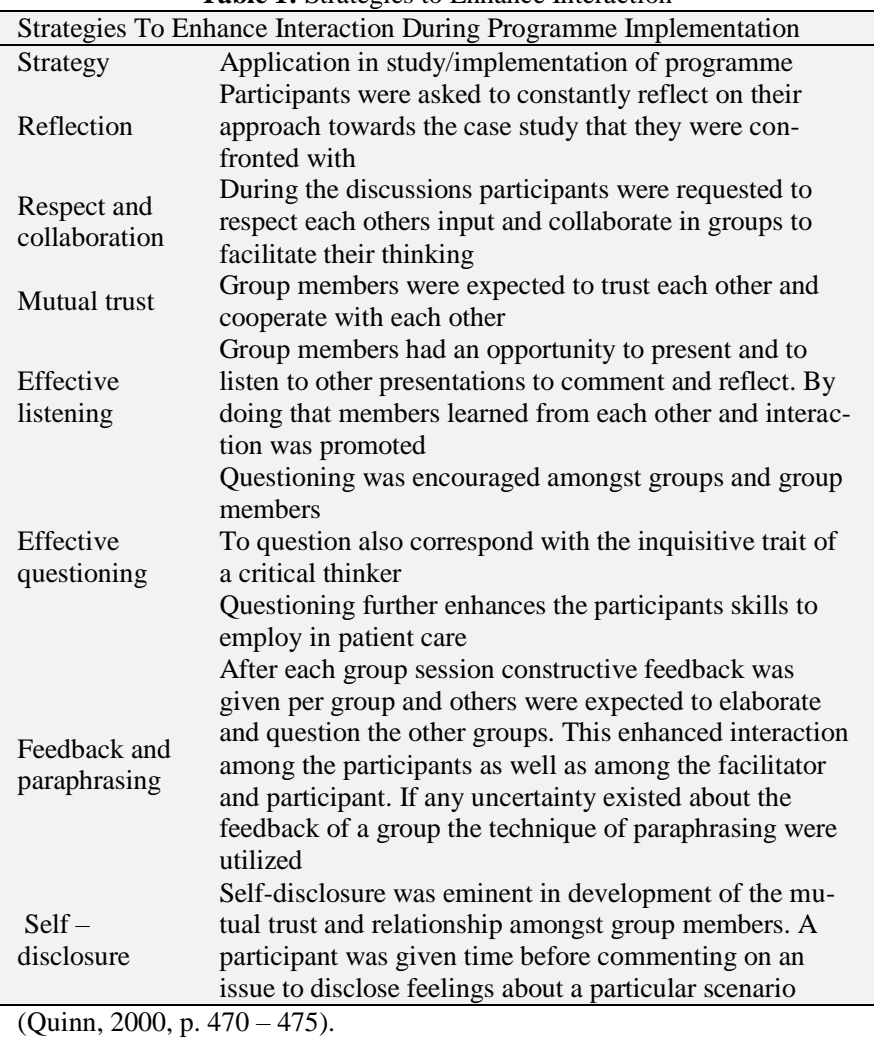

\subsection{Educational and curriculum approaches integrated into the development of an educational programme}

An eclectic approach to the development of this educational programme was applied. Different curriculum and educational approaches were utilized in the design of the educational programme.

The researcher strove to keep the programme simple but not simplistic, to serve as a guide to the nursing student in everyday nursing practice. The educational programme had an outcomes-based focus, namely to facilitate the development of critical thinking skills by the student nurse. Outcomes are described by Zundel, Needham, Richards, Kershaw, Daugharty and Robak (n.d., p. 2) as educational targets, something that the facilitator expected to achieve. The latter authors also emphasize that, during outcomesbased learning, students are assisted in the achievement of certain targets, namely, in this educational programme, the application and development of critical thinking skills. This can be achieved through courses that are assignment-centered rather than textbook and lecture centered (Mihram, n.d.,; Gellin \& Beard, 2007).

The educational programme was developed within the principles of adult learning/andragogics, as indicated in the model of Knowles (Schoenly, 1998; Quinn \& Hughes, 2007), and in support thereof constructivistic teaching principles were emphasized ( as discussed with philosophical approaches ).

The cyclic curriculum development model as presented by Nicholls and Nicholls (1978), the curriculum development model related to critical thinking by Videbeck (Feingold \& Perlich, 1999) and Duldt's framework on debating critical thinking were also utilized as part of the framework for the development of the educational programme as indicated in figure 2.

- Cyclic curriculum development model of Nicholls and 
With the principles of adult education and constructivism in mind, the researcher also utilized a specific method to develop the educational programme for this study. As mentioned previously, the curriculum model of Nicholls and Nicholls was used (figure $2 \&$ figure 6).

The curriculum development model of Nicholls and Nicholls depicts curriculum development as a continuing process. This is very relevant to critical thinking. The model emphasizes the fact that actions within the curriculum are interrelated and interactive, and that no actions can take place in a vacuum. Since the model represents a circular process, it is indicative of an ongoing process with no particular starting or finishing point, based on a situational analysis. The following five actions are evident in this model:

- Conducting a situational analysis

- Selecting objectives

- Selecting and organizing content

- Selecting and organizing teaching methods

- Evaluation (Nicholls \& Nicholls 1978).

Other authors (Mentkowski \& Associates, 2000) also support the process model of Nicholls and Nicholls. The researcher therefore decided to apply this model for the development of the educational programme.

The application of this model to the educational programme developed for this study, to facilitate the development of critical thinking in student nurses, resulted in the following actions:

- A situational analysis was done in phase 1 to determine to what extent senior nursing students are able to execute and apply critical thinking in the management of a specific nursing case. On the basis of this analysis specific objectives to address in the educational programme were formulated. It is important to mention that the programme objectives related to the needs as identified in the situational analysis

- Content to assure the achievement of the objectives was constructed and suitable teaching methods designed to go with the content.

- During implementation of the programme emphasis in the choice of teaching methods was on active participation by the participants in the educational programme.

- Evaluation of the programme content was done by means of a pretest and posttest, before and after the programme, to determine whether there had been any change in the application of critical thinking skills by the student nurses after attending the programme.

Videbeck's model of curriculum development

In addition to the process model of Nicholls and Nicholls, the researcher found it appropriate to use Videbeck's curriculum model (Feingold \& Perlich, 1999) simultaneously with Nicholls and Nicholls's model (1978) as described, as an additional approach to the development of the educational programme (fig $2 \&$ fig 3 ). This model includes four phases, which perfectly corresponded to the four actions of Nichols \& Nicholls's cyclic curriculum model. These four phases were to describe the concept critical thinking, identify critical thinking outcomes, plan strategies to foster critical thinking skills and to evaluate student achievement during exercises of application of critical thinking (Feingold \& Perlich, 1999).

The application of this model to the educational programme for senior student nurses can be described as follows:

- The concept critical thinking was addressed and described in both the presentation of the educational programme and the handout that was provided to the participants.

- Clear outcomes for this educational programme with regard to critical thinking and its application thereof were formulated, namely that the student would "demonstrate the use of critical thinking in the execution of nursing care in addressing the patient's need".

- Specific strategies were designed for the educational programme to foster the development of critical thinking skills during nursing practice. The strategies focused on active participation by the participant during the educational programme
- The students' ability to apply critical thinking was assessed by the facilitator of the programme (the researcher) by introducing a pretest before the programme and a posttest after completion of the programme. These tests were conducted to determine whether any change(s) had taken place in the application of critical thinking skills by students, and if so, whether these changes could be ascribed to the educational programme to facilitate the critical thinking skills of senior student nurses.

Knowles model on andragogy

Knowles developed an andragogical model that accommodates continuing education and training for adult learners, a group which includes nursing students. Andragogy is a term that "belongs" to and refers to adult education as described by Knowles and is defined as "the art and science of helping adults learn" (Knowles, 1980, p. 43; Merriam \& Brockett, 1997; Quinn \& Hughes, 2007

Knowles realized that adults learn differently from the way children learn and he was also of the opinion that people learn best when treated as human beings during a lifelong process of education. Moreover, it is necessary to keep in mind that adult learners carry with them the baggage of their expectations of learning derived from formal schooling and that a mind shift might be necessary to get them to feel at ease with the "new" environment. For this mind shift to take place it is necessary to have an adult educator who plan and administers programmes and who counsels and facilitates learning by creating awareness in a certain subject (Heimlich \& Norland, 1994; Merriam \& Brockett, 1997; Richardson, 1998).

For the adult educator to establish this mind shift of the learner, the following elements in this process model should be kept in mind. The adult educator needs to do the following:

- Establish a climate conducive to learning; referring to the physical, human and interpersonal environment.

- Create a mechanism for mutual planning, a cardinal principle of andragogy.

- Diagnose the needs for learning where the adult learner has to realize his own needs and perceptions.

- Design a pattern of learning experiences where self-directed learning features prominently.

- Formulate and operate a programme by setting clear objectives.

- Evaluate a programme with a five-step approach, namely ongoing evaluation, learning evaluation, behaviour evaluation, results evaluation and re-diagnosis of learning needs (Dekker, 1998; Quinn \& Hughes, 2007).

The concept of adult learning is supported by Caffarella and Barnett (1994), who state that most adults prefer to be actively involved versus being primarily passive recipients of knowledge. Active learning involves the student through participation and an investment of energy in all phases of the learning process. However, adults fear failure, which implies that the educator or facilitator of the programme should ensure a relaxed, psychologically safe environment where empowerment of the learner can be facilitated (Courtney, 1992; Norton, 1998(b); Norton, 1998,; LevettJones, 2005).

In support of the andragogical model as described, the development of the educational programme focused on cooperative learning as based on the beliefs of constructivism. Constructivism in teaching suggests that people learn through an interaction between thinking and experience and it encourages cooperative learning and therefore enhances active participation as suggested by Knowles. Integrating a constructivist approach to the adult learning principles seemed logical and applicable to this study, since the approach can be adapted to any subject (Shaw, 2006; Gagnon \& Collay, n.d.; Murphy, 1997; Pollard, 2002,).

The incorporation of Knowles's process model on andragogy and constructivism into the educational programme to facilitate the development of critical thinking, for this study, was done in the following way:

- All participants of the educational programme were adult learners involved in tertiary education. 
- The participants were fourth-year nursing students with nursing experience to fall back on when confronted with new nursing problems.

- The strategy followed for the educational programme was that of active participation where the learners were involved in discussions and planning. However, they were not actively involved in the setting of the objectives of the educational programme because the programme was based on the needs that were identified by a needs assessment during phase 1 of the study;

- Clear objectives were formulated for the programme, which was offered over three days.

- The activities were self-directed to promote active participation and inquiry.

- Small group discussions were employed to enhance cooperative learning and build trust between members of the group, through face to face interaction.

- Groups were expected to give feedback on their progress in the cases presented during the implementation of the educational programme.

- An evaluation was done before and after the programme by a pre- and post-test to determine whether the application of critical thinking skills had improved.

(Levett-Jones, 2005; Gagnon \& Collay, n.d; Baumberger-Henry, 2005; Gagnon \& Collay, n.d,; Quinn \& Hughes, 2007).

In addition to the above, people need to be prepared to think critically to be able to distinguish between important and less important issues and this can be achieved through adult education. Two more aspects are important in adult education and support constructivism, namely the recognition of prior experience and knowledge in the class discussions and learning activities that are "situated" as near as possible to reality so that students can transfer learning more easily. These learning activities refer to the creation of very real scenarios whereby the teacher/facilitator encourages students to engage in active learning and gives them everbroadening tools to enable them to keep learning. By integrating these, the emphasis of the constructivistic approach to learning is on individualized rather than mass learning (Carafella \& Barnett, 1994; ThirteenEd Online, 2004,; Carlisle \& Ibbotson, 2005; Banning, 2005; Davis, Kumtepe \& Aydeniz, 2007).

By taking active participation into account, the researcher aimed to include as many exercises from nursing practice and everyday life as possible, in order to encourage students to exercise their skills pertaining the situations and to use their knowledge base to solve the case scenarios. Because adult learners have broad stores of knowledge and varied experience, they can assist each other to learn (Fosnot, 1996; Meyer, Naude \& Van Niekerk, 2004).

From the above, the roles of the adult learner and the educator/facilitator within the educational programme were summarized and are reflected in table 2

Table 2: Roles of the Educator and the Learner in Adult Education, Incorporating Constructivism [The activities of the educator and the learner do not necessarily correlate with each other in the table.]

\begin{tabular}{|c|c|}
\hline duc & Learners \\
\hline $\begin{array}{l}\text { - Relate to the learners with re- } \\
\text { spect } \\
\text { - Create a psychologically safe en- } \\
\text { vironment to facilitate learning } \\
\text { with mutual respect and ac- } \\
\text { ceptance of differences } \\
\text { - Introduce learners to the clear } \\
\text { objectives of the programme }\end{array}$ & $\begin{array}{l}\text { - Accept responsibility for } \\
\text { collaborating in planning } \\
\text { activities } \\
\text { - Adopt goals of the pro- } \\
\text { gramme as their own } \\
\text { goals } \\
\text { - Actively participate in the } \\
\text { learning experience } \\
\end{array}$ \\
\hline
\end{tabular}

- Involve learners in assessing and determining their needs

- Help learners to optimally make use of their experience

- Assist learners to meet the learning objectives

- Assist learners to help develop their learning activities

- Promote active participation of the learner through self-directed activities

- Encourage participation and cooperation with other learners

- Introduce learners to situations where they can explore and find self-fulfillment

- Assist learners in evaluating themselves and the programme

- Acknowledge prior learning and experience

(Fosnot, 1996 , p. ix; Feldman, 2002, p. 20; Pollard, 2002, p.159; Thirteen

Ed Online, 2004, p.1; Meyer, Naude \& Van Niekerk, 2004, p. 89).

\section{- Duldts' framework on debating critical thinking}

The researcher also incorporated the framework on debating critical thinking as presented by Duldt (1997) into the development of the educational programme (figure 2 and figure 3 ). Duldt believes that defining and debating concepts is the core of critical thinking. The author stipulates that there are three sets of data facilitators can use to determine the level of critical thinking of students (Duldt, 1997)

These are as follows:

- The first is the most superficial level of "figuring things out" which occurs at the verbal level through discussions with the students. For this educational programme this level was determined by talking to students during the programme and listening to what they had to say about their everyday practice

- The second level is a bit harder and includes "reading" how others have figured something out. This was applied by presenting a case scenario to the students and then observing how they "figured it out".

- The third and hardest way is the writing part of "figuring it out". The facilitator can then look carefully at the structure and substance of what the students presented. As applied to the educational programme for this research, this level was assessed in the answers of students to the questions of the case scenario used in the pre-and post-test of the quasiexperimental design.

Duldt further holds the opinion (1997) that critical thinking should be learned over a period of time. For the purposes of this research, a condensed educational programme was offered to a selected group of students over a period of three days. Information vital to the discipline of nursing was handled and facilitated by the facilitator. The focus of the programme was on thinking rather than on learning. This supports the critical theory, which indicates that it is important to teach students how to think rather than what to think (Glen, 1995; Duldt, 1997).

A schematic presentation on the development of the educational programme follows in fig 2 


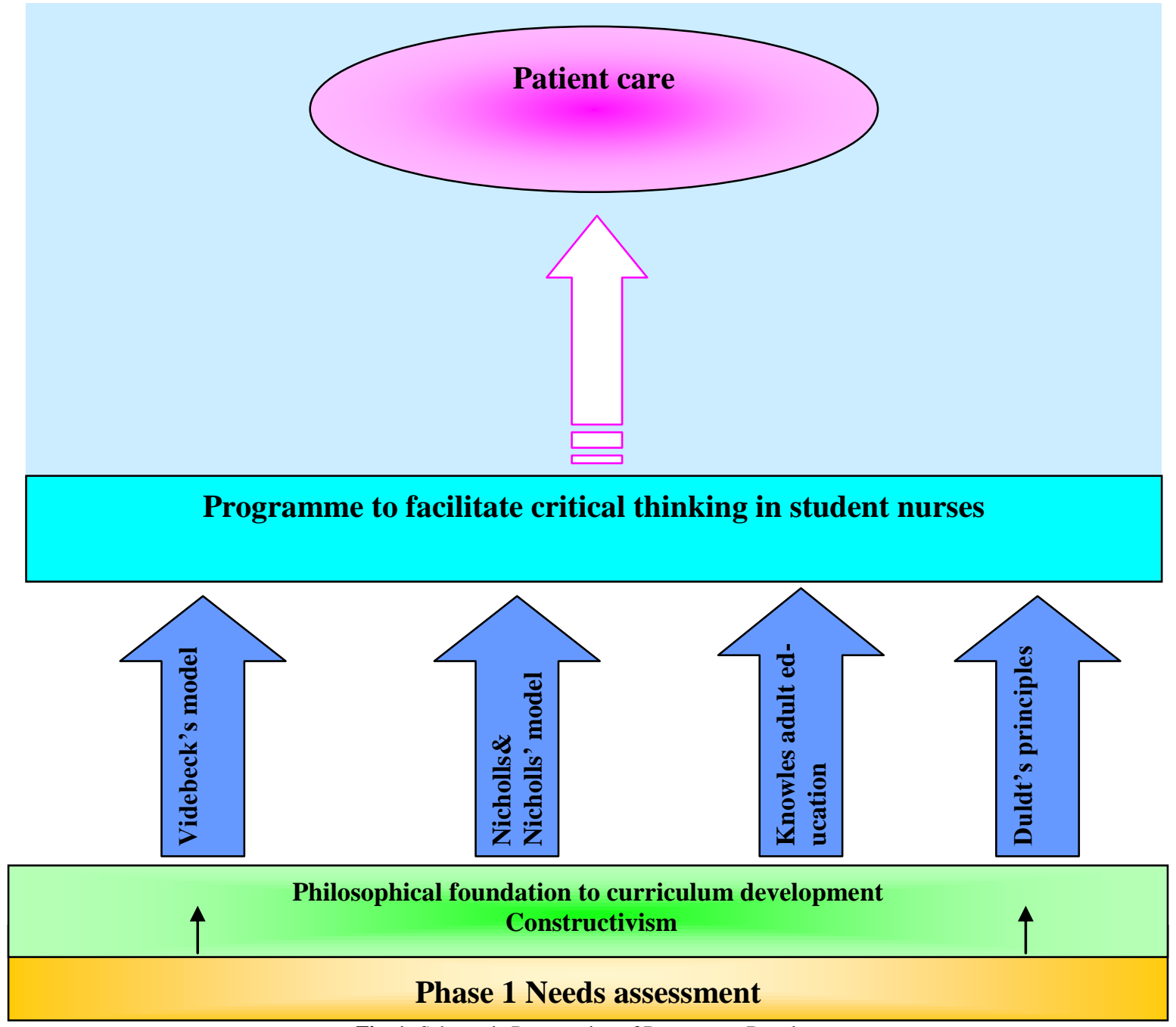

Fig. 1: Schematic Presentation of Programme Development.

The researcher incorporated different components of the development of the educational programme in the cyclic model to curriculum development. The incorporation of these components is presented in Figure 6.5.

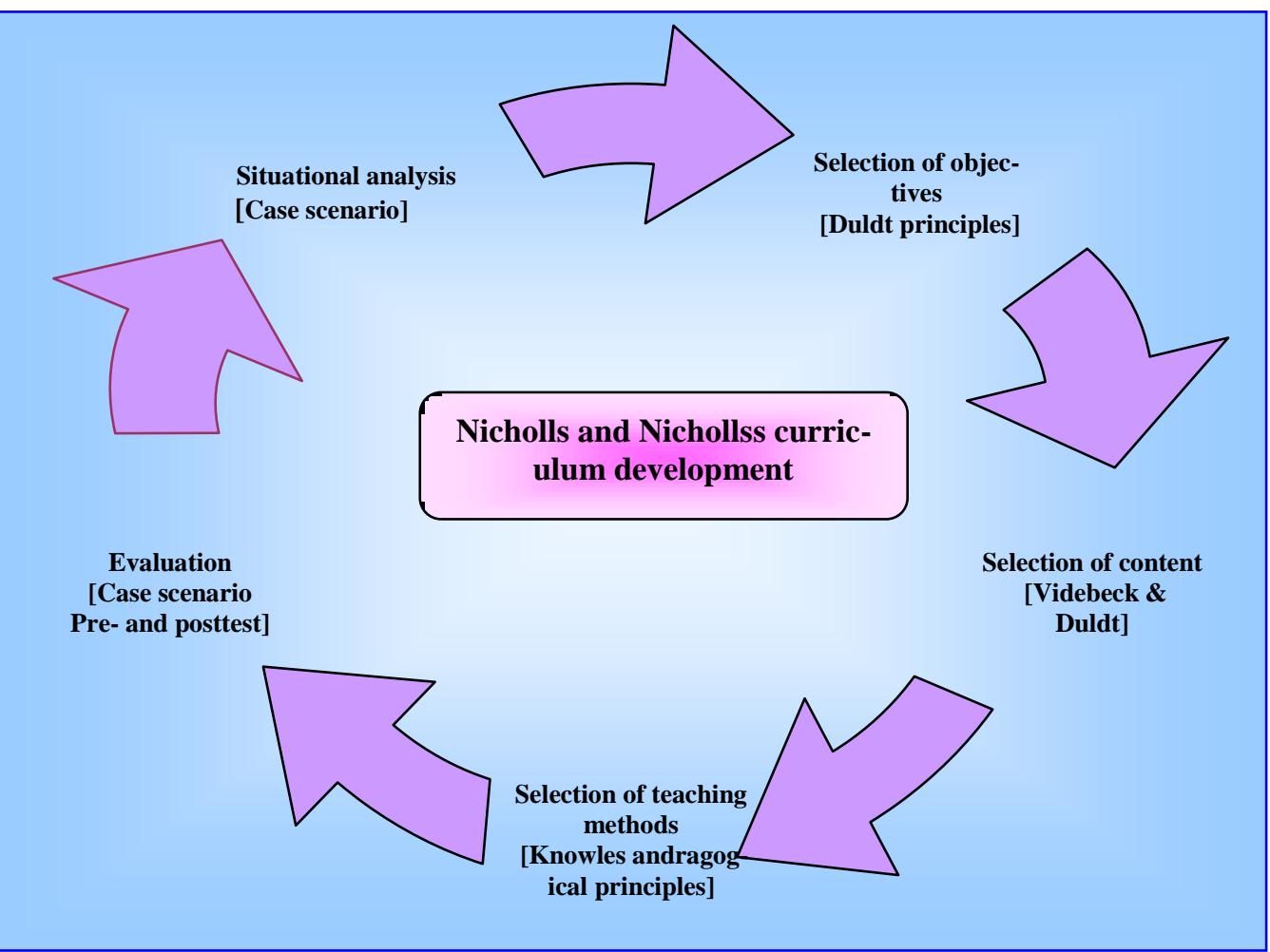

Fig. 2: Schematic Presentation of Integrated Components within Nicholls and Nicholls's Cyclical Model to Curriculum Development. 
Designing the implementation of the educational programme is a logical step to execute after the process of programme development as indicated in fig 6.4 .

The components of the researcher's curriculum cycle as original contribution is summarized in figure 3.

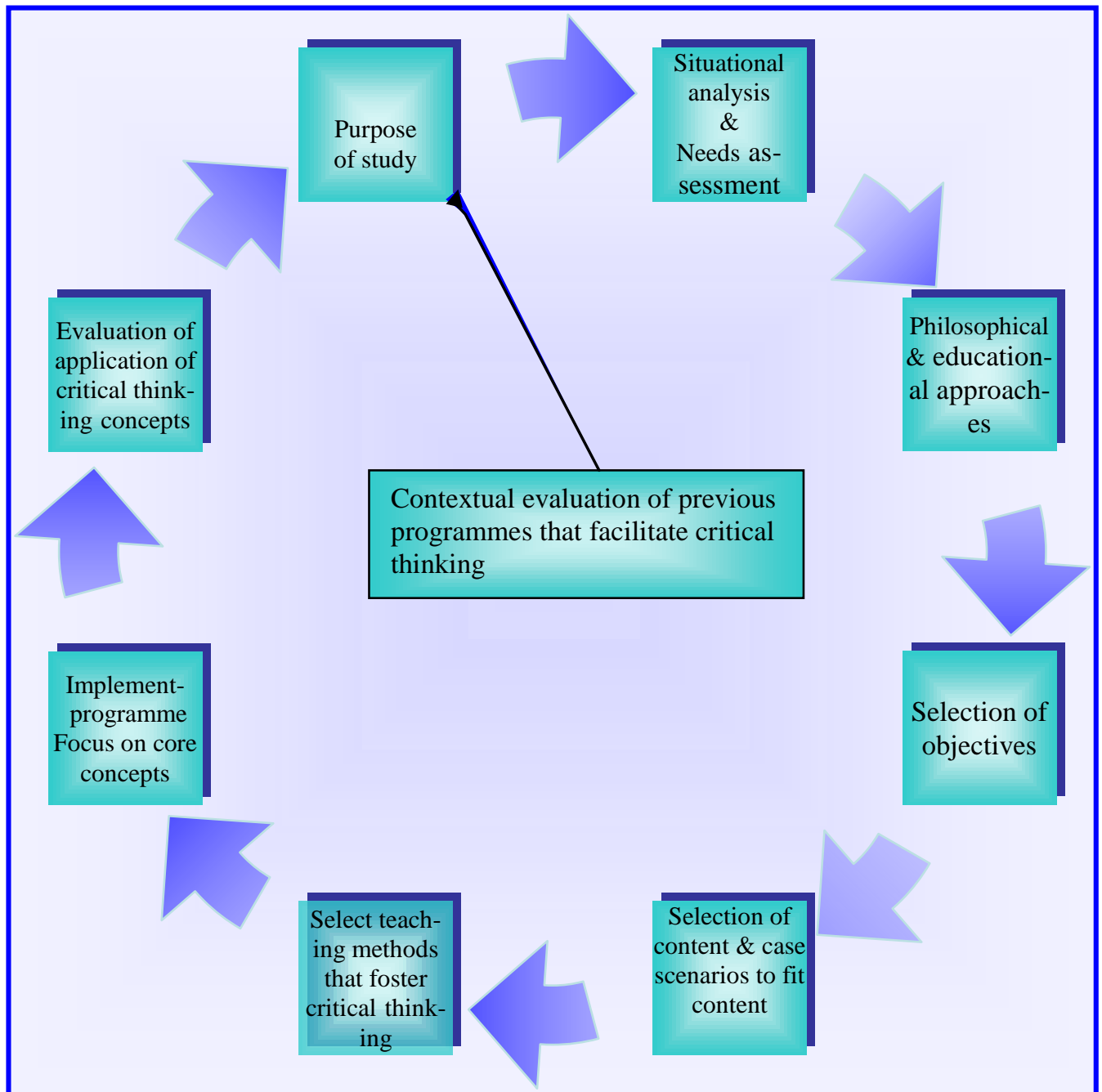

Fig. 3: Schematic Presentation of the Researcher's Integrated Curriculum Cycle for a Programme to Facilitate Critical Thinking.

\subsection{Strategies to overcome obstacles during the imple- mentation of an educational programme}

Though many obstacles that may occur in the facilitation of critical thinking during the presentation of an educational programme were mentioned in chapter 2, the researcher, during the development of this educational programme, focused on strategies to employ in order to overcome these obstacles in this programme. Those applied strategies are indicated in table 6.4.

Table 3: Strategies to Overcome Obstacles in Facilitation of Critical Thinking

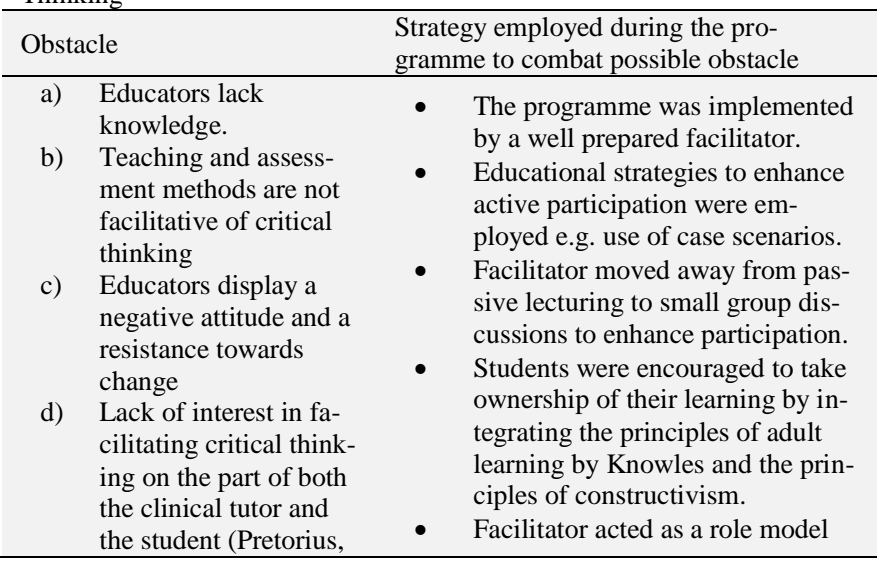

\begin{tabular}{ll}
\hline 2001, p.113). & $\begin{array}{l}\text { for critical thinking and enhanced } \\
\text { positive attitudes among student } \\
\text { nurses. } \\
\text { The teaching environment turned } \\
\text { out to be very relaxed and stimu- } \\
\text { lating. } \\
\text { - Facilitator convinced students that } \\
\text { it is necessary to enter into dia- } \\
\text { logue with each other and with the } \\
\text { facilitator so that both parties got } \\
\text { used to the utilization of active } \\
\text { participation in teaching to facili- } \\
\text { tate critical thinking. } \\
\text { Facilitator provided opportunities } \\
\text { for student to participate in active } \\
\text { discussion. }\end{array}$ \\
\hline (Pretorius, 2001, p.113; Cooke \& $\begin{array}{l}\text { Moyle, 2002, p. 335; Mangena \& } \\
\text { Chabeli, 2005, p.294). }\end{array}$
\end{tabular}

\section{Outcomes and conclusion}

The educational programme to facilitate critical thinking of student nurses which was developed comprised the six components, namely (i) Programme outline for the participants focused on general information, course specifics, course objectives, evaluation of the course, programme content and instructional methodology (ii) Programme design for the participants; (iii) programme introduction (iv) supplementary programme material comprised of what is critical thinking, traits of a critical thinker, profile of a critical 
Thinker, critical thinking in the context, major critical thinking concepts and strategies promoting critical thinking. (v) Conclusion and (VI) practical exercises. For whole document of the programme to facilitate development of critical thinking in student nurses you can contact the author at lpretorius@unam.na

The development of the educational programme for this study may benefit the Namibian community since the quality of nursing care will be enhanced if student nurses and professional nurses can think critically. The question is, however, whether students are prepared for such a challenge in a complex, changing world and how nurse educators can encourage students to look beyond the obvious in clinical nursing to address complex nursing problems (Robinson, 1998; Dillard \& Laidig, 1998).

\section{References}

[1] Richardson, V. (1998). The diverse learning needs of students. In D.M. Billings \& J.A. Halstead (Eds.), Teaching in nursing (pp.1731). Tokyo: Saunders

[2] Facione, N.C., Facione, P.A., Giancarlo, C.A.F. (1997 (a)). The motivation to think in working and learning. In E. Jones (Ed.), preparing competent college graduates: Setting new and higher expectations for student learning (pp. 67-79). San Fransisco, CA: JosseyBass.

[3] Facione P.A., Facione, N.C., Giancarlo, C.A.F. (1997). Professional judgment and the disposition toward critical thinking. Milbrae: California Academic Press.

[4] Jenkins, P., \& Turick-Gibson, T. (1999). An exercise in critical thinking using role playing. Nurse Educator, 24(6), 11-4. http://dx.doi.org/10.1097/00006223-199911000-00009.

[5] Gellin, M.A. \& Beard, M. (2007). Infusing critical thinking and diversity: Easy or hard? Retrieved May 2, 2007 from http://www.mc.maricopa.edu/community/chair/conference2007/doc uments/infusingcriticalthinking.pdf.

[6] Pond, E., Bradshaw, M.J., \& Turner, S. (1991). Teaching strategies for critical thinking. Nurse Education, 16(6), 18-22. http://dx.doi.org/10.1097/00006223-199116060-00007.

[7] Fichardt, A.E., \& Viljoen, M.J. (2000). Assessment of learning needs and the development of an educational program for registered nurses in advanced midwifery and neonatology. Curationis, 23(4), 107-116. http://dx.doi.org/10.4102/curationis.v23i4.768.

[8] Banning, M. (2005). Approaches to teaching: Current opinions and related research. Nurse Education Today, 25(7), 502-508. http://dx.doi.org/10.1016/j.nedt.2005.03.007.

[9] ADEA (American Dental Education Association). (2006). Educational strategies associated with development of problem solving, critical thinking and self-directed learning. Journal of Dental Education, 70 (9), 925-936.

[10] Anastasi, J. (2004). Re-entry to nursing: student focus in the competence assessment service program. SLEID (Studies in Learning, Evaluation, Innovation and Development), 1(1), 8-15.

[11] Richardson, V. (1998). The diverse learning needs of students. In D.M. Billings \& J.A. Halstead (Eds.), Teaching in nursing (pp.1731). Tokyo: Saunders

[12] CTL (Center for Teaching and Learning). (2005). Speaking of teaching. Stanford University Newsletter, 15(1), 1-6. Retrieved May 15, 2007, from http://ctl.stanford.edu.

[13] Van Gelder, T. (n.d). Teaching critical thinking. Some lessons from cognitive science. College teaching, 45(1), 1-6. Retrieved August 02, 2006, from http:// www.philosophy.unimelb.edu.au/reason/papers/Teaching_CT- lessons.pdf

[14] Sternberg, R.J., \& Spear-Swerling, L. (1996). Teaching for thinking. Washington: American Psychological Association. http://dx.doi.org/10.1037/10212-000.

[15] Abegglen, J. (1997). Critical thinking in nursing: Classroom tactics that work. Journal of Nursing Education, 36 (10), 452 - 458.

[16] Fosnot, C.T. (1996). Constructivism: Theory, perspectives and practice. London: Teachers College Press.

[17] Mentkowski, M. \& Associates. (2000). learning that lasts: Integrating learning, development, and performance in college and beyond. San Francisco: Jossey Bass.

[18] Applegate, M.H. (1998). Curriculum evaluation. In D.M. Billings \& J.A Halstead (Eds.), Teaching in nursing ( pp 179 - 205). Tokyo: Saunders.

[19] Redding, D.A. (2001a). The development of critical thinking among students in Baccalaureate nursing education. Holistic Nurs- ing Practice, 15(4), 57-64. http://dx.doi.org/10.1097/00004650200107000-00009.

[20] Stone, C.A., Davidson, L. J., Evans, J.L., \& Hansen, M.A. (2001). Validity evidence for using a general critical thinking test to measure nursing students' critical thinking. Holistic Nursing Practice, 15 (4), 65-74. http://dx.doi.org/10.1097/00004650-200107000-00010.

[21] Oberleitner, M.G. (n.d). Responding in writing to clinical cases: The development of clinical reasoning in nursing. Retrieved September 04, 2006, from http://wac.colostate.edu // $1 \mathrm{lad} / \mathrm{v} 5 \mathrm{nl} /$ oberleitner.

[22] Redding, D.A. (2001a). The development of critical thinking among students in Baccalaureate nursing education. Holistic Nursing Practice, 15(4), 57-64. http://dx.doi.org/10.1097/00004650200107000-00009.

[23] Wright, I. (2002). Is that right? Critical thinking and the social world of the young learner. Toronto: Pippin.

[24] Mentkowski, M. \& Associates. (2000). learning that lasts: Integrating learning, development, and performance in college and beyond. San Francisco: Jossey Bass.

[25] Jensen, E. (2006). Enriching the brain: how to maximize every learner's potential. San Fransisco: Jossey-Bass.

[26] Fichardt, A.E., \& Viljoen, M.J. (2000). Assessment of learning needs and the development of an educational program for registered nurses in advanced midwifery and neonatology. Curationis, 23(4), 107-116. http://dx.doi.org/10.4102/curationis.v23i4.768

[27] Thorpe, K., \& Loo, R. (2003). Critical thinking types among nursing and management undergraduates. Nurse Education Today, 23(8), 566-574. http://dx.doi.org/10.1016/S0260-6917(03)00102-3.

[28] Facione, N.C., Facione, P.A., Giancarlo, C.A.F. (1994). Critical thinking disposition as a measure of competent clinical judgment: The development of the California Critical Thinking Disposition Inventory. Journal of Nursing Education, 33(8), 345-350.

[29] Facione, N.C., Facione, P.A., Giancarlo, C.A.F. (1997 (a)). The motivation to think in working and learning. In E. Jones (Ed.), preparing competent college graduates: Setting new and higher expectations for student learning (pp. 67-79). San Fransisco, CA: JosseyBass.

[30] Facione P.A., Facione, N.C., Giancarlo, C.A.F. (1997). Professional judgment and the disposition toward critical thinking. Milbrae: California Academic Press.

[31] Facione, P.A. (1998). Critical thinking: what it is and why it counts [Electronic version]. Retrieved January 23, 2006 from http://www.calpress.com/pdf.files/what \& why.

[32] Facione, P.A. (2006). Critical thinking: what it is and why it counts [Electronic version]. 2006 Update. Retrieved January 23, 2006 from: http://www.calpress.com/pdf.files/what \& why.

[33] Csokasy, J. (1998). Philosophical Foundations of the Curriculum. In D.M. Billings \& J.A. Halstead (Eds.), Teaching in nursing (pp 97-116). Tokyo: Saunders.

[34] Praeger, S.G. (1995). Josephine Paterson and Loretta T Zderad: The base for professional nursing practice. In J.B. George (Ed.), Nursing theories. (4th ed.) . Norwalk: Appleton \& Lange.

[35] Dillard, N., \& Laidig, J. (1998). Curriculum development: an overview. In D.M Billings \& J.A. Halstead (Eds.), Teaching in nursing (pp 69-81). Tokyo: Saunders.

[36] Praeger, S.G. (1995). Josephine Paterson and Loretta T Zderad: The base for professional nursing practice. In J.B. George (Ed.), Nursing theories. (4th ed.) . Norwalk: Appleton \& Lange.

[37] Dillard, N., \& Laidig, J. (1998). Curriculum development: an overview. In D.M Billings \& J.A. Halstead (Eds.), Teaching in nursing (pp 69-81). Tokyo: Saunders.

[38] Polit, D.E., \& Beck,C.T. (2006). Essentials of nursing research. (6th ed.). Philadelphia. Lippincott Williams \& Wilkins.

[39] Polit, D.E., \& Beck, C.T. (2004). Nursing research: Principles and methods. (7th ed.). Philadelphia. Lippincott Williams \& Young.

[40] Wikipedia. (n.d (a)). Constructivism (learning theory). Retrieved July 2, 2005, from http://en.wikipedia.org/wiki/Constructivism.

[41] Murphy, E. (1997). Characteristics of constructivist learning \& teaching. Retrieved May 15, 2007 from http://www.stemnet.nf.ca/elmurphy/emurphy/cle3.html.

[42] Robinson, D.L. (1998). Clinical decision making for nurse practitioners: A case study approach. Washington: Lippincott-Raven.

[43] Sternberg, R.J. (1985). Teaching critical thinking. PHI DELTA KAPPAN. December. 277-280.

[44] Cooke, M., \& Moyle, K. (2002). Students' evaluation of problem based learning. Nurse Education Today, 22(4), $330-339$ http://dx.doi.org/10.1054/nedt.2001.0713.

[45] Baumberger-Henry, M. (2005). Cooperative learning and case study: does the combination improve students' perception of prob- 
lem-solving and decision making skills? Nurse Education Today, 25(3), 238-246. http://dx.doi.org/10.1016/j.nedt.2005.01.010.

[46] Thurmond, V.A. (2001). The holism in critical thinking: A concept analysis. Journal of Holistic Nursing, 19(4), 375-388. http://dx.doi.org/10.1177/089801010101900406.

[47] Souers, C. (2002). Teaching strategies. Nurse Educator, 27 (1), 912. http://dx.doi.org/10.1097/00006223-200201000-00011.

[48] Siegel, C. (2005). The Journal of Educational Research, 98(6), 339349. http://dx.doi.org/10.3200/JOER.98.6.339-349.

[49] Smith-Stoner, M. (1999). Critical thinking activities for nursing. Philadelphia. Lippincott.

[50] Sternberg, R.J. (1985). Teaching critical thinking. PHI DELTA KAPPAN. December. 277-280.

[51] Pond, E., Bradshaw, M.J., \& Turner, S. (1991). Teaching strategies for critical thinking. Nurse Education, 16(6), 18-22. http://dx.doi.org/10.1097/00006223-199116060-00007.

[52] Jenkins, P., \& Turick-Gibson, T. (1999). An exercise in critical thinking using role playing. Nurse Educator, 24(6), 11-4. http://dx.doi.org/10.1097/00006223-199911000-00009.

[53] Varner, D., \& Peck, S.R. (2003). Learning from learning journals: The benefits and challenges of using learning journal assignments. Journal of Management Education, 27(1), 23-77. http://dx.doi.org/10.1177/1052562902239248.

[54] Zundel, P.E., Needham, T.D., Richards, E.W., Kershaw, J.A. Daugharty, D.A., \& Robak, E.W. (n.d). Fostering competency with outcome based assessment. Retrieved July 06, 2006, from http://www.snr.missouri.edu/meetings/uenv/zundel.outcome.pdf.

[55] Mihram, D. (n.d). Creating an objective based syllabus. Retrieved July 06, 2006, from http://www.usc.edu/programs/cet/private/ppt/resources/syllabuswor kshop.ppt.

[56] Schoenly, L. (1998). Staff development programs: Strategic thinking applied. In K.J. Kelly-Thomas (Ed.). Clinical and nursing staff development: Current competence, future focus (2nd ed., pp 192 212). Philadelphia: Lippincott.

[57] Quinn, F.M., \& Hughes, S.J. (2007). Quinn's principles and practice of nurse education. (5th ed.). Cheltenham: Stanley Nelson.

[58] Nicholls, A., \& Nicholls, S.H. (1978). Developing a curriculum. A practical guide. London. Allen \& Unwin

[59] Knowles, M.S. (1980). The modern practice of adult education. Chicago. Follett.

[60] Knowles, M.S. (1990). The adult learner: A neglected species. (4th ed.). Houston. Gulf.

[61] Kozier, B., Erb, G., Berman, A., \& Snyder, S.J. (2004). Fundamentals of nursing. Concepts process and practice. (7th ed.). New Jersey. Pearson Education.

[62] Heimlich, J.E., \& Norland, E. (1994). Developing teaching style in adult education. San Fransisco, CA: Jossey-Bass

[63] Merriam, S.B., \& Brockett, R.G. (1997). The profession and practice of adult education: An introduction. San Fransisco. CA Jossey-Bass.

[64] Dekker, E.I. (1998). The provision of adult education. In E.I. Dekker \& E.M Lemmer (Eds.), Critical Issues in Modern Education (pp 275-333). Durban: Heinemann.

[65] Courtney, S. (1992). Why adults learn: Towards a theory of participation in adult education. London: Routledge.

[66] Norton, B. (1998). Selecting learning experiences to achieve curriculum outcomes. In D.M. Billings \& J.A. Halstead (Eds.), Teaching in nursing (pp. 151-169). Tokyo: Saunders

[67] Norton, B. (1998 b). Selecting learning experiences to achieve curriculum outcomes. In D.M. Billings \& J.A. Halstead (Eds.), Teaching in nursing (pp. 211-245). Tokyo: Saunders.

[68] Shaw, L.J. (2006). Teacher Education 954. Humanistic and Socia Aspects of Teaching. Five educational philosophies. Existentialism. Retrieved September 09, 2006, from http://edweb.sdsu.edu/LShaw/f95syll/phlos/phexist.html.

[69] Gagnon, G.W. \& Collay, M. (n.d). Constructivist learning design. Retrieved May 15, 2007, from http://www.prainbow.com/cld/cldp.html.

[70] Murphy, E. (1997). Characteristics of constructivist learning \& teaching. Retrieved May 15, 2007 from http://www.stemnet.nf.ca/elmurphy/emurphy/cle3.html.

[71] Pollard, A. (2002). Reflective teaching: Effective and evidenceinformed professional practice. London: Continuum.

[72] Levett-Jones, T.L. (2005). Self-directed learning: Implications and limitations for undergraduate nursing education. Nurse Education $\begin{array}{lrrr}\text { Today, } & 25 & \text { (5), }\end{array}$ http://dx.doi.org/10.1016/j.nedt.2005.03.003.
[73] Gagnon, G.W. \& Collay, M. (n.d). Constructivist learning design. Retrieved May 15, 2007, from http://www.prainbow.com/cld/cldp.html.

[74] Thirteen|Ed online. (2004). Concept to classroom: Constructivism as paradigm for teaching and learning. Retrieved February 06, 2008, from

http://www.thirteen.org/edonline/concept2class/constructivism/inde x.html.

[75] Carlisle, C \& Ibbotson, T. (2005). Introducing problem-based learning into research methods teaching: Student and facilitator evaluation. Nurse Education Today, 25 (7), 527-541. http://dx.doi.org/10.1016/j.nedt.2005.05.005.

[76] Banning, M. (2005). Approaches to teaching: Current opinions and related research. Nurse Education Today, 25(7), 502-508. http://dx.doi.org/10.1016/j.nedt.2005.03.007.

[77] Davis, N.T., Kumtepe, E.G., Aydeniz, M. (2007). Fostering continuous improvement and learning through peer assessment: Part of an integral model of assessment. Educational Assessment, 12(2), 112135. http://dx.doi.org/10.1080/10627190701232720.

[78] Fosnot, C.T. (1996). Constructivism: Theory, perspectives and practice. London: Teachers College Press.

[79] Meyer, S.M., Naude, M., \& van Niekerk, S. (2004). The unit manager: A comprehensive guide. Sandton: Heinemann.

[80] Duldt, B.W. (1994). Critical thinking. Nurse Educator, 19(6), 9-10. http://dx.doi.org/10.1097/00006223-199411000-00008.

[81] Pretorius, L. (2001). The role of the clinical nurse instructor in the development of critical thinking in the student nurses in Namibia. MArts (Nursing Science) dissertation, University of Namibia. Windhoek.

[82] Cooke, M., \& Moyle, K. (2002). Students' evaluation of problem based learning. Nurse Education Today, 22(4), 330 -339. http://dx.doi.org/10.1054/nedt.2001.0713.

[83] Mangena, A., \& Chabeli, M. (2005). Strategies to overcome obstacles in the facilitation of critical thinking in nursing education. Nurse Education Today, 25(4), 291-298 http://dx.doi.org/10.1016/j.nedt.2005.01.012.

[84] Robinson, D.L. (1998). Clinical decision making for nurse practitioners: A case study approach. Washington: Lippincott-Raven.

[85] Dillard, N., \& Laidig, J. (1998). Curriculum development: an overview. In D.M Billings \& J.A. Halstead (Eds.), Teaching in nursing (pp 69-81). Tokyo: Saunders. 